\title{
Anaemia Among Children Who Attended the Children's Teaching Hospital in Karbala, Iraq
}

\author{
Khansaa Albaroodi (D) \\ Pharmacy Department, Al Zahrawi \\ University College, Karbala, Iraq
}

Correspondence: Khansaa Albaroodi Pharmacy Department, Al Zahrawi University College, Karbala Al-Najaf Highway, Karbala, 5600I, Iraq Tel +9647727009050

Email khansaa.albaroodi@hotmail.com
Introduction: The World Health Organization (WHO) reported a moderate incidence of anaemia among pregnant and nonpregnant women and among children younger than 59 months in 2011.

Purpose: The aim of this study was to investigate anaemia among children younger than 14 years submitted to haematological exams at the Children's Teaching Hospital in Karbala, Iraq.

Patients and Methods: This was a cross-sectional study carried out in the Children's Teaching Hospital Laboratory Department in Karbala, Iraq, from 1 July 2019 until 1 September 2019.

Results: The prevalence of anaemia among children aged 0-14 years in Karbala was 9.9\%. There was no significant relationship between the type of anaemia diagnosed and age or sex. However, there was a significantly positive relationship between the type of anaemia diagnosed and each ferritin level, mean corpuscular volume, and mean corpuscular haemoglobin $(\mathrm{p}<0.0001)$. The study participant skull diameter and length in relation to sex were compared to the WHO reference values for child growth standards, and the study values were less than the normal range for children below 5 years of age.

Conclusion: A high prevalence of anaemia among children was reported with its apparent consequence on their health. This study highlights the prevalence of anaemia among children up to 14 years of age in Karbala, and future research is encouraged.

Keywords: anaemia, children with anaemia, prevalence, thalassemia

\section{Introduction}

Anaemia is a widespread health problem that affects children in both developing and well-developed countries and has major consequences for human health in addition to social and economic development; anaemia can occur at any age. ${ }^{1}$ Anaemia is a health condition in which there is an inadequate number of red blood cells or their oxygen-carrying capacity to meet the body's physiological needs. Iron deficiency is the main reason for anaemia; however, there are other causes of anaemia, such as folate, vitamin B12 and vitamin A deficiencies, chronic inflammation, parasitic infections, and inherited disorders, which can all cause anaemia. ${ }^{1,2}$ Haemoglobin or haematocrit levels are the most common tools used to assess the severity of iron deficiency in any population. The health consequences of anaemia can lead to many undesired outcomes, such as poor pregnancy outcomes, impaired physical and cognitive development, increased risk of morbidity in children and reduced work productivity in adults. ${ }^{1-3}$

The WHO determined that approximately two billion people are anaemic, which is defined as haemoglobin $(\mathrm{Hb})$ concentrations that are below recommended thresholds. ${ }^{2}$ 
Iron deficiency-induced anaemia is an important public health problem in the Eastern Mediterranean region. In the "Assessment of the Food and Nutrition Situation in Iraq" of May-June 2000, approximately 800,000 children under 5 were chronically malnourished. The report also indicated a high prevalence of anaemia in school children; additionally, the numbers of infants with low birth weight and women with severe anaemia have increased. ${ }^{4}$ It has been estimated that more than one-third of the population in the region is anaemic. Pregnant women and young children are the most at risk: approximately $50 \%$ of pregnant women and $63 \%$ of children under 5 have iron deficiency-induced anaemia. Recent data on anaemia rates in preschool children, pregnant women and women of childbearing age show no improvement in the overall situation. ${ }^{2}$ The WHO considers anaemia a severe public health problem in Iraq $(55.9 \%$ of the preschool population in Iraq had $\mathrm{Hb}<110 \mathrm{~g} / \mathrm{L}) ;{ }^{1}$ however, these results had no clinical evidence to rely on because of a lack of research and data in this area during that time. ${ }^{1}$ In 2011, the WHO reported that Iraq had a moderate incidence of anaemia among pregnant and nonpregnant women and children younger than 59 months. ${ }^{5}$ Many studies have investigated the incidence of anaemia among children worldwide. ${ }^{6-9}$

By reviewing studies that focus on anaemia in Iraq, we found a study that investigated the classification of anemia in Iraq. ${ }^{10}$ Another study by Taj-Eldin investigated thalassemia in Iraq. ${ }^{11}$ A trial to estimate the prevalence of sickle cell disease was conducted among primary school children. ${ }^{12}$ More recently, studies were carried out in Iraq to estimate the prevalence of anaemia; ${ }^{13-16}$ thalassemia; ${ }^{17}$ anaemia and hookworm; ${ }^{18}$ anaemia and pregnancy; ${ }^{19-21}$ anemia among rheumatoid arthritis patients; ${ }^{22}$ and Helicobacter pylori and iron deficiency anaemia. ${ }^{23}$ It is obvious that these studies are limited and inadequate to support any updates in the documentation regarding anaemia in Iraq. Therefore, this research was carried out to emphasize the prevalence of anaemia in one of Iraq governorates, Karbala. This study aimed to investigate anaemia among children younger than 14 years submitted to haematological exams at the Children's Teaching Hospital in Karbala, Iraq.

\section{Patients and Methods}

This was a cross-sectional study carried out in the Children's Teaching Hospital Laboratory Department in Karbala, Iraq, from 1 July 2019 until 1 September 2019. During July 2019, 1179 outpatients attended the hospital, which was close to the number of outpatients who attended the hospital during August 2019 (1170 outpatients). Among those patients, we collected data on 234 anaemic patients, and those patients agreed to participate in the study by signing a consent form. As the Children's Teaching Hospital is the only hospital for children in Karbala, we can calculate the prevalence of anaemia among children aged 0-14 years in Karbala, which was 9.9\%.

Researchers collected patient information during their visit to the laboratory department by abstracting the patients' haematology results from their records (haemoglobin, haematocrit (HCT), Mean corpuscular volume (MCV), mean corpuscular haemoglobin (MCH) and red blood cell (RBC) were measured by using Sysmex; ferritin was measured by using Cobas e 411; and thalassemia was measured by using Bio Rad D10). Researchers measured the patient skull diameter (by using a measuring tape wrapped around the widest possible circumference) and length (also by using a measuring tape) to compare the growth of these children with the standard average. Data were analysed by using the SPSS (version 20) software package (SPSS Inc., Chicago, IL) and are presented as the frequency in tables and figures as appropriate. The Shapiro-Wilk test for normality was applied to the continuous data (skull diameter and length), and these data were normally distributed $(\mathrm{p}>0.05)$. Pearson's chi-square test and one-way ANOVA were used to find the association and differences, respectively, between variables. The skull diameter and length in relation to the child's sex were compared to the WHO reference value child growth standards. $^{24}$

A $p$ value $<0.05$ was considered significant.

\section{Results}

After collecting information from the participant's records, data were analysed, revealing that the participant mean age was $4.1 \pm 3.4$ years, and the mean skull diameter and length were $48.6 \pm 4.6 \mathrm{~cm}$ and $98.6 \pm 24.5 \mathrm{~cm}$, respectively. Table 1 summarizes the study participant demographic data; more than two-thirds of the participants were younger than 5 years. Approximately, two-thirds of the study participants were recently diagnosed with anaemia, and more than half of them had mild iron deficiencyinduced anaemia, which makes it reasonable that most of them were not using any medications to treat anaemia.

Patients with thalassemia had a separate centre in the hospital, and by reviewing centre records, we found that the proportion of these patients increased over time (Figure 1).

As shown in Table 2, laboratory values were categorized according to the Children's Teaching Hospital Laboratory Department in Karbala, Iraq. The vast majority of the study 
Table I Study Participant Demographic Data

\begin{tabular}{|l|c|}
\hline & Frequency (\%) \\
\hline Sex & $132(56.4)$ \\
Female & $102(43.6)$ \\
Total & $234(100)$ \\
\hline Age & \\
Less than 5 years & $166(70.9)$ \\
5-II years & $54(23.1)$ \\
I2-I4 years & $14(6)$ \\
Total & $234(100)$ \\
\hline Time of diagnosis & \\
Recently diagnosed & $152(65)$ \\
Less than 6 months & $42(17.9)$ \\
More than 6 months & $40(17.1)$ \\
\hline Type of anaemia diagnosed & \\
Mild IDA* & $138(59)$ \\
Moderate IDA* & $73(31.2)$ \\
Severe IDA* & $9(3.8)$ \\
Thalassemia & $5(2.1)$ \\
Normochromic normocytic anaemia & $9(3.8)$ \\
Total & $234(100)$ \\
\hline Using medications for anaemia & $72(30.8)$ \\
Yes & $234(100)$ \\
No & \\
Total & \\
\hline
\end{tabular}

Abbreviation: *IDA, iron deficiency anaemia.

participants had low levels of ferritin, haemoglobin, MCV, $\mathrm{MCH}$ and HCT, which is logical as far as they are anaemic.

Pearson's chi-square test was used to examine whether there was a relationship between the type of anaemia diagnosed and each of the following: age, sex, ferritin, red blood cells (RBCs), MCV, MCH, and HCT. The results showed that there was no significant relationship between the type of anaemia diagnosed and age or sex. On the other hand, the type of anaemia diagnosed had a significantly $(\mathrm{P}<0.0001)$ positive relationship with ferritin level (chisquare value $=234, \mathrm{df}=8, \mathrm{R}=0.35$ ), $\mathrm{MCH}$ (chi-square value $=107.5, \mathrm{df}=8, \mathrm{R}=0.435$ ), and $\mathrm{MCV}$ (chi-square value $=46.1, \mathrm{df}=4, \mathrm{R}=0.26$ ). However, the relationship with RBC count was significantly negative (chi-square value $=55.3, \mathrm{df}=8, \mathrm{R}=-0.29$ ) (Table 3 ).

Table 4 displays the mean \pm SD of the study participant skull diameter and length in relation to sex and compared to WHO standards. It was obvious that the mean participant skull diameter and length were smaller than the normal range for children below 5 years of age.

\section{Discussion}

This study revealed that the most common type of anaemia in Karbala was iron deficiency-induced anaemia, and patients did not use any medications to treat it. Microcytic and hypochromic anaemia can be caused by IDA and thalassemia to the same extent; ${ }^{25,26}$ some patients had both conditions and received treatment for only one of them, as the other was not diagnosed..$^{27}$ Differentiation between thalassemia and IDA can be carried out effectively with serum ferritin, serum iron and $\mathrm{HbA}_{2}$ level estimation; however, recent data suggest that the red cell distribution width (RDWI) is more advantageous, as all discriminating factors, including $\mathrm{RBC}$ count, $\mathrm{MCV}$ and RDW, are incorporated. ${ }^{28}$ Another study used the mean corpuscular haemoglobin concentration and red blood cell

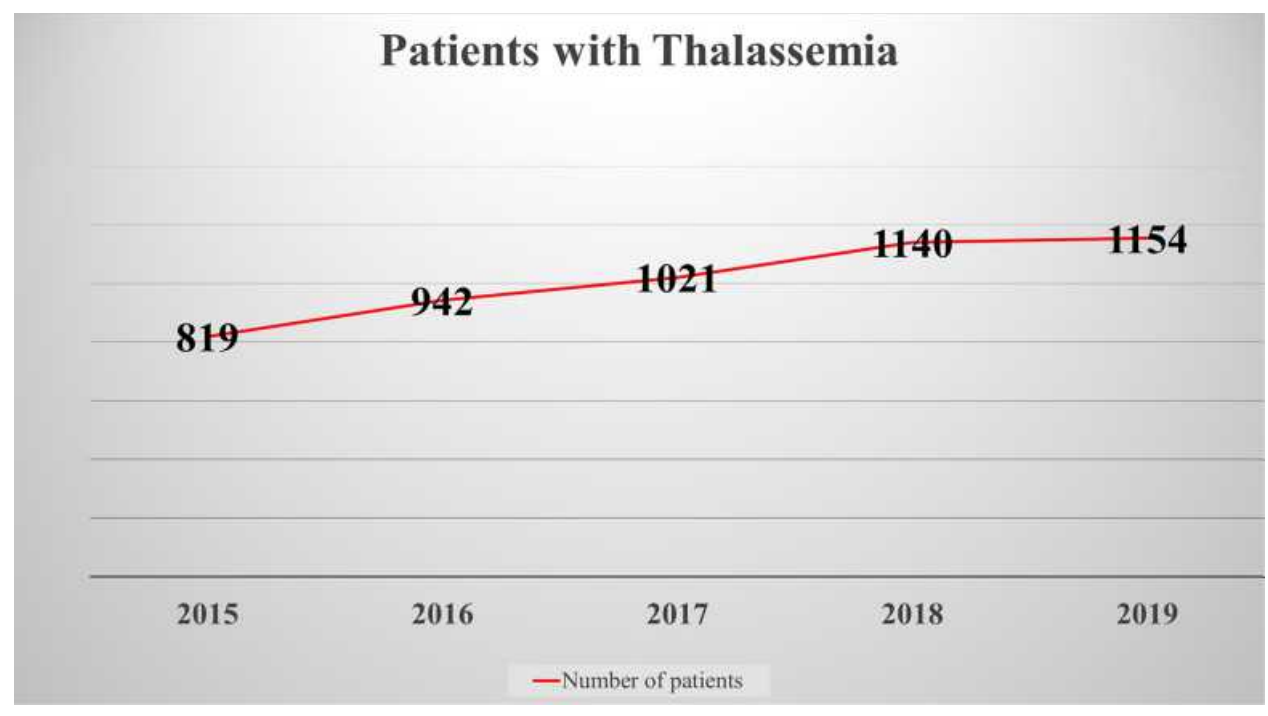

Figure I Patients with thalassemia. 
Table 2 Study Participant Haematology Laboratory Values

\begin{tabular}{|c|c|}
\hline & Frequency (\%) \\
\hline \multicolumn{2}{|l|}{ Ferritin level } \\
\hline Low $<30(\mu \mathrm{g} / \mathrm{L})$ & $229(97.9)$ \\
\hline Normal $(30-400)(\mu \mathrm{g} / \mathrm{L})$ & $4(1.7)$ \\
\hline High $>400(\mu \mathrm{g} / \mathrm{L})$ & $\mathrm{I}(0.4)$ \\
\hline Total & $234(100)$ \\
\hline \multicolumn{2}{|l|}{ RBC level } \\
\hline Low $<4.06\left(10^{\wedge} 6 / \mathrm{uL}\right)$ & $26(11 . I)$ \\
\hline Normal (4.06-5.30) (10^6/uL) & $206(88)$ \\
\hline High $>5.30\left(10^{\wedge} 6 / \mathrm{uL}\right)$ & $2(0.9)$ \\
\hline Total & $234(100)$ \\
\hline \multicolumn{2}{|l|}{ Haemoglobin } \\
\hline Low <12 (g/dl) & $234(100)$ \\
\hline Normal (I2-I6) (g/dl) & 0 \\
\hline \multicolumn{2}{|l|}{ MCV level } \\
\hline Low $<76 \mathrm{fL}$ & $207(88.5)$ \\
\hline Normal (76-96) fL & $27(11.5)$ \\
\hline Total & $234(100)$ \\
\hline \multicolumn{2}{|l|}{$\mathrm{MCH}$ level } \\
\hline Low $<26$ pg & $218(93.2)$ \\
\hline Normal (26-32) pg & $15(6.4)$ \\
\hline High $>32 \mathrm{pg}$ & $\mathrm{I}(0.4)$ \\
\hline Total & $234(100)$ \\
\hline \multicolumn{2}{|l|}{ HCT level } \\
\hline Low $<38 \%$ & $233(99.6)$ \\
\hline Normal (38-52)\% & I (0.4) \\
\hline Total & $234(100)$ \\
\hline
\end{tabular}

Abbreviations: RBCs, red blood cells; MCV, mean corpuscular volume; $\mathrm{MCH}$, mean corpuscular haemoglobin; HCT, haematocrit.

count to differentiate iron deficiency-induced anaemia from thalassemia. ${ }^{29}$ However, a review article showed that despite the excellent performances of the Green and King index (IGK), the Ehsani index, and RBC count, none of them presented sufficient sensitivity and specificity to establish a diagnosis between thalassemia and IDA, and these tests require more time-consuming and costly methods. ${ }^{30}$ As mentioned earlier, there is a limitation in studies that investigate the prevalence of anaemia in Iraq; to the best of our knowledge, this is the first study to investigate this aspect among children in Karbala, Iraq. Our findings showed that the prevalence of anaemia among children aged 0-14 years in Karbala was $9.9 \%$, which is considered high. A study by Faraj, Lami et al showed similar findings to ours; a high prevalence of anaemia among children in Wasit, Iraq, indicates a major nutritional and health problem. ${ }^{15}$ Another study carried out in Baghdad in 2003 found that anaemia among adolescents was a health problem of moderate severity. ${ }^{13}$ These results show that anaemia in Iraq may be related to malnutrition and poverty. A cross-sectional study was conducted to determine the overall and age- and sex-specific prevalence of anaemia in the city of Mashhad, Iran. The findings show that anaemia is a considerable public health problem in Mashhad, Iran, especially among preschool children, adult women and the elderly. ${ }^{8}$

Our study findings revealed that there was no relation between the type of anaemia and age or sex. In agreement with these results, a cross-sectional study was carried out to determine the prevalence of anaemia among preschool children in a rural village in the Northern State of Sudan and showed that the prevalence of anaemia was not significantly associated with any of the studied demographic and socioeconomic factors (sex, economic status of the family, mother's literacy or family size) or the health of the child. ${ }^{6}$ Additionally, another study in Istanbul showed no significant relationship between the prevalence of anaemia and student age or sex. ${ }^{31}$ On the other hand, a study was carried out to assess the health and nutrition of Syrian refugees affected by the conflict; the results showed that global acute malnutrition is relatively low in the assessed Syrian refugee populations. However, these study results indicate a serious public health problem among women and children, especially in the Zaatari camp. ${ }^{7}$ Another study investigated the prevalence of ID and IDA among Syrian children, the effectiveness of oral iron supplements in the management of ID, and the diagnostic effectiveness of conventional iron markers. The results revealed a high prevalence of anaemia, ID, and IDA among a group of apparently healthy Syrian children. ${ }^{9}$ However, this aspect can be considered a limitation in our study, as we did not investigate nutritional levels among the participants.

Our study findings showed that there were more male participants than females in the study sample, indicating that anaemia is more common among males than females; agreeing with our findings, Gür, Yıldız et al reported a markedly higher risk for anaemia and Fe deficiency in men, indicating higher Fe requirements in boys than in girls, ${ }^{31}$ and another study carried out in Wasit showed similar findings. ${ }^{15}$ In addition, many studies have investigated anaemia and pregnancy; a study in Baqubah found that anaemia during pregnancy is a major health problem, and iron deficiency anaemia was common. ${ }^{19}$ On the other hand, another study among emigrated Yazidis people in the Khanki camp in Duhok, a city in Iraqi Kurdistan, found that iron deficiency-induced anaemia had a high prevalence among residents of this camp, especially among pregnant women. In addition, there was a strong 
Table 3 Relationship Between the Type of Anaemia Diagnosed and Haematology Parameters

\begin{tabular}{|c|c|c|c|c|c|c|c|c|c|c|}
\hline & & \multicolumn{5}{|c|}{ Type of Anaemia Diagnosed } & \multirow{2}{*}{$\begin{array}{c}\text { Pearson's } \\
\text { Chi- } \\
\text { Square } \\
\text { Value }\end{array}$} & \multirow[t]{2}{*}{ df } & \multirow[t]{2}{*}{$P$ value } & \multirow{2}{*}{$\begin{array}{c}\text { Pearson's } \\
\text { R Value }\end{array}$} \\
\hline & & $\begin{array}{l}\text { Mild } \\
\text { IDA }\end{array}$ & $\begin{array}{c}\text { Moderate } \\
\text { IDA }\end{array}$ & $\begin{array}{c}\text { Severe } \\
\text { IDA }\end{array}$ & Thalassemia & $\begin{array}{c}\text { Normochromic } \\
\text { Normocytic } \\
\text { Anaemia }\end{array}$ & & & & \\
\hline \multirow[t]{2}{*}{ Sex } & Female & 56 & 34 & 6 & 2 & 4 & 2.75 & 4 & 0.66 & -0.055 \\
\hline & Male & 82 & 39 & 3 & 3 & 5 & & & & \\
\hline \multirow[t]{3}{*}{ Age } & $\begin{array}{l}<5 \\
\text { years }\end{array}$ & 95 & 51 & 9 & 5 & 6 & 14.6 & 8 & 0.066 & -0.006 \\
\hline & $\begin{array}{l}5-11 \\
\text { years }\end{array}$ & 38 & 15 & 0 & 0 & I & & & & \\
\hline & $\begin{array}{l}12-14 \\
\text { years }\end{array}$ & 5 & 7 & 0 & 0 & 2 & & & & \\
\hline \multirow[t]{3}{*}{ Ferritin } & Low & 138 & 73 & 9 & 0 & 9 & 234 & 8 & $<0.0001$ & 0.35 \\
\hline & Normal & 0 & 0 & 0 & 4 & 0 & & & & \\
\hline & High & 0 & 0 & 0 & I & 0 & & & & \\
\hline \multirow[t]{3}{*}{ RBC } & Low & 6 & 10 & 4 & 2 & 4 & 55.3 & 8 & $<0.0001$ & -0.29 \\
\hline & Normal & 132 & 62 & 5 & 2 & 5 & & & & \\
\hline & High & 0 & I & 0 & I & 0 & & & & \\
\hline \multirow[t]{2}{*}{ MCV } & Low & 120 & 73 & 9 & 4 & I & 64.1 & 4 & $<0.0001$ & 0.26 \\
\hline & Normal & 18 & 0 & 0 & I & 8 & & & & \\
\hline \multirow[t]{3}{*}{$\mathrm{MCH}$} & Low & $|3|$ & 72 & 9 & 5 & 1 & 107.5 & 8 & $<0.0001$ & 0.435 \\
\hline & Normal & 7 & I & 0 & 0 & 7 & & & & \\
\hline & High & 0 & 0 & 0 & 0 & 1 & & & & \\
\hline \multirow[t]{2}{*}{ HCT } & Low & 137 & 73 & 9 & 5 & 9 & 0.69 & 4 & 0.951 & -0.042 \\
\hline & Normal & 1 & 0 & 0 & 0 & 0 & & & & \\
\hline
\end{tabular}

Abbreviations: IDA, iron deficiency anaemia; RBCs, red blood cells; MCV, mean corpuscular volume; MCH, mean corpuscular haemoglobin; HCT, haematocrit.

significant relationship between iron deficiency-induced anaemia and low serum zinc. ${ }^{20}$ Furthermore, a cross-sectional study was carried out in Al-Diwaniyah, Iraq, and showed that maternal anaemia affects the anthropometric measurements of newly delivered full-term neonates. ${ }^{21}$ Our study showed an increase in the incidence of thalassemia over time, a warning sign to work towards minimizing its risks. Conversely, another study investigated the prevalence of thalassemia minor among college students in Kurdistan (7.7\%). ${ }^{17}$ In Basrah, a study investigated haemoglobinopathies and glucose-6-phosphate dehydrogenase (G6PD) deficiency and found that there was an association between G6PD deficiency and haemoglobinopathies and thalassemia. ${ }^{14}$ Many studies were carried out in Iraq to find any relationship between anaemia and other diseases. ${ }^{16,18,22,23}$ However, poor quality of life in Iraq can be the main reason for this high prevalence, as indicated by a recent study that found an association between selected water and sanitation indicators and anaemia. ${ }^{32}$ Our study findings show that the mean participant skull diameter and length were under the normal range for children below 5 years of age, which indicates that poor nutrition and anaemia affected child growth in this sample.

\section{Conclusion}

In conclusion, participants with IDA took over the essential element among other types of anaemia existing in Karbala Iraq, and their need to be treated is one of the priorities. This study highlights the prevalence of anaemia among children up 
Table 4 Mean Participant Skull Diameter and Length in Relation to Age and Sex

\begin{tabular}{|c|c|c|c|c|c|c|}
\hline \multirow[t]{2}{*}{ Sex } & \multirow{2}{*}{$\begin{array}{l}\text { Age } \\
\text { Group }\end{array}$} & \multirow[t]{2}{*}{$\mathbf{N}$} & \multicolumn{2}{|c|}{ Skull Length } & \multicolumn{2}{|c|}{ Skull Diameter } \\
\hline & & & $\begin{array}{l}\text { Study Participants } \\
\text { Mean } \pm \text { SD }(\mathrm{cm})\end{array}$ & $\begin{array}{l}\text { Reference Length }(\mathrm{cm}) \\
\text { Less Than } 5 \text { Years }\end{array}$ & $\begin{array}{l}\text { Study Participants } \\
\text { Mean } \pm \text { SD }(\mathbf{c m})\end{array}$ & $\begin{array}{l}\text { Reference Skull diameter } \\
\text { (cm) Less Than } 5 \text { Years }\end{array}$ \\
\hline Female & $\begin{array}{l}\text { Less than } \\
5 \text { years } \\
5-11 \\
\text { years } \\
12-14 \\
\text { years } \\
\text { Total }\end{array}$ & $\begin{array}{r}63 \\
32 \\
7 \\
102\end{array}$ & $\begin{array}{r}85.1 \pm 15.2 \\
126.9 \pm 12.1 \\
145 \pm 9.7 \\
102.3 \pm 26.4\end{array}$ & 118.4 & $\begin{array}{l}46.3 \pm 4.6 \\
52.6 \pm 2.2 \\
55.6 \pm 4.3 \\
48.9 \pm 5.2\end{array}$ & 52.6 \\
\hline Male & $\begin{array}{l}\text { Less than } \\
5 \text { years } \\
5-11 \\
\text { years } \\
12-14 \\
\text { years } \\
\text { Total }\end{array}$ & $\begin{array}{r}100 \\
28 \\
4 \\
132\end{array}$ & $\begin{array}{l}85.8 \pm \mid 5.1 \\
124.7 \pm 9.9 \\
140.5 \pm 8.8 \\
95.7 \pm 22.6\end{array}$ & 118.7 & $\begin{array}{l}47 \pm 3.8 \\
52 \pm 1.6 \\
52.5 \pm 2.6 \\
48.3 \pm 1\end{array}$ & 53.5 \\
\hline
\end{tabular}

to 14 years of age in Karbala, and future studies should be encouraged to link anaemia with other environmental and nutritional factors that play an important role in its incidence.

\section{Acknowledgments}

The author would like to thank Rusul Abdulkareem and Rusul Mohammad for their outstanding efforts as well as Dr. Mohammad Al Mousawy for his support and assistance with his valuable and profound comments.

\section{Institutional Review Board Statement}

The study was conducted according to the guidelines of the Declaration of Helsinki and was approved by the Institutional Review Board of Al-Zahrawi University College (ZUC Approval at 01-09-2019). All parents or legal guardians of the children provided informed consent before participating in the study.

\section{Disclosure}

The author has no conflicts of interest to declare.

\section{References}

1. World Health Organization. Worldwide prevalence of anaemia 1993-2005: WHO global database on anaemia; 2008. Available from: https://apps.who.int/iris/bitstream/handle/10665/43894/ 9789241596657_eng.pdf? sequence=1. Accessed December 01, 2019.

2. World Health Organization, Centers for Disease Control and Prevention. Assessing the Iron Status of Populations: Including Literature Reviews. Geneva, Switzerland: World Health Organization, Centers for Disease Control and Prevention; 2004.
3. Hoffbrand AV, Moss PAH. Hoffbrand's Essential Haematology. 7th ed. Wiley-Blackwell; 2016.

4. Kreisel W. Health Situation in Iraq. Brussels: World Health Organization; 2001.

5. World Health Organization. The global prevalence of anaemia in 2011; 2015; Available from: https://apps.who.int/iris/bitstream/han dle/10665/177094/9789241564960_eng.pdf. Accessed December 18, 2019.

6. Hussein MD, Mohamed S. Prevalence of anaemia in preschool children in Karma Albalad area, Northern State, Sudan. East Mediterr Health J. 2014;20(1):33-38. doi:10.26719/2014.20.1.33

7. Hossain SMM, Leidman E, Kingori J, Al Harun A, Bilukha OO. Nutritional situation among Syrian refugees hosted in Iraq, Jordan, and Lebanon: cross sectional surveys. Confl Health. 2016;10(1):26. doi:10.1186/s13031-016-0093-6

8. Iman EM, Reza HMM, Farhad F, Reza BH, Khosro SS. Anemia as a public health issue in Mashhad, Iran: evidence from the first population-based study. Acta Med Iran. 2015;53(3):186-190.

9. Albaroudi IN, Khodder M, Al Saadi T, Turk T, Youssef LA. Prevalence, diagnosis, and management of iron deficiency and iron deficiency anemia among Syrian children in a major outpatient center in Damascus, Syria. Avicenna J Med. 2018;8(3):92-103. doi:10.4103/ ajm.AJM_169_17

10. Jalili MA, Demarchi M. Classification of anemia in Iraq. $J$ Fac Med Baghdad. 1952;16(3/4):71-100.

11. Taj-Eldin S, Al-Rabii H, Jawad J, Fakhri O. Thalassaemia in Iraq. Ann Trop Med Parasitol. 1968;62(2):147-153. doi:10.1080/ 00034983.1968 .11686542

12. Alkasab FM, Al-Alusi FA, Adnani MS, Alkafajei AM, Al-Shakerchi $\mathrm{NH}$, Noori SF. The prevalence of sickle cell disease in Abu-ALKhasib district of southern Iraq. J Trop Med Hyg. 1981;84(2):77-80.

13. Al-Sharbatti SS, Al-Ward NJ, Al-Timimi DJ. Anemia among adolescents. Saudi Med J. 2003;24(2):189-194.

14. Hassan MK, Taha JY, Al-Naama LM, Widad NM, Jasim SN. Frequency of $B$-thalassaemia, haemoglobin $S$ and glucose-6- phosphate dehydrogenase deficiency in Basra governorate, Iraq. East Mediterr Health J. 2003;9.

15. Faraj SA, Lami JKA, Jabar HNA, Hassan UMAA. Epidemiological character of anemia among Wasit Province children, Iraq. Adv Med Dent Res. 2016;1(1):11-14. 
16. Aboud SF, Al-Tu'ma FJ, Alkarem LA. Correlation of vitamin $\mathrm{D}$ deficiency and hyperparathyroidism with anemic in Female Iraqi. Iraqi Natl J Chem. 2017;17(1):34-43.

17. Alnakshabandi AA, Muhammad HA. Prevalence of B-thalassemia carriers among a cohort of university students in Hawler Province of Iraqi Kurdistan. Iraqi J Pharm Sci. 2009;18(2).

18. Kamil ZH, Rashid KH, Al-Awad AS. The prevalence of anemia and hookworm ancylostoma duodenale infection in Mishamish Village, Al-Hashimya District, Babylon Province, Iraq. Med J Babylon. 2014;11(4)

19. Salman ST, Hussein AA. Determine morphological types of anemia in anemic pregnant women in albatool teaching hospital for maternity and children in Baqubah City, Iraq. Inte $J$ Adv Res. 2016;4 (5):934-939. doi:10.21474/IJAR01/448

20. Ahmad HM. Anemia and iron deficiency anemia prevalence with serum zinc assessment among emigrated yazidis people in khanki camp in Duhok city, Kurdistan Region, Iraq.. J Dent Med Sci. 2016;15(10):105-110.

21. Al-Hajjiah NN, Almkhadree MA. The effect of maternal anemia on the anthropometric measurements in fullterm neonates. Asian J Pharm Clin Res. 2018;11(4):422-424. doi:10.22159/ajpcr.2018. v11i4.25579

22. Getta HA, Khoshnaw N, Alwan AF, Mirza RR. Types of anaemia and its correlation with disease activity in patients with rheumatoid arthritis among kurdish population of Iraq. Iraqi J Hematol. 2016;5 (1).

23. Rashid NG, Ahmed FF, Abdulla BK, Yassin AK, Al Ani MH. The relation between helicobacter pylori seropositivity and iron deficiency anaemia in Iraq-Kurdistan-Sulaimani City. J Sulaimani Coll Med. 2018;8(1):17-21. doi:10.17656/jsmc.10146

24. World Health Organization. WHOChild Growth Standards Growth Velocity Based on Weight, Length and Head Circumference. Methods and Development. Geneva: World Health Organization; 2009:262.
25. Lin CK, Chen LP, Chang HL, Sung YC. Underestimation of the coexistence of iron deficiencies and thalassemia minors: a single institution experience in Taiwan. Kaohsiung $J$ Med Sci. 2014;30 (8):409-414. doi:10.1016/j.kjms.2014.03.010

26. Akers AS, Howard D. Distinguishing iron deficiency anaemia from thalassemia trait in clinical obstetric practice. J Pregnancy Reprod. 2017.

27. Verma S, Gupta R, Kudesia M, Mathur A, Krishan G, Singh S. Coexisting iron deficiency anemia and beta thalassemia trait: effect of iron therapy on red cell parameters and hemoglobin subtypes. ISRN Hematol. 2014;2014:293216. doi:10.1155/2014/293216

28. Jameel T, Baig M, Ahmed I, Hussain MB, Alkhamaly MBD. Differentiation of beta thalassemia trait from iron deficiency anemia by hematological indices. Pak J Med Sci. 2017;33(3):665-669. doi:10.12669/pjms.333.12098

29. Matos JF, Dusse LMS, Borges KBG, Castro RLV, Coura-Vital W, Carvalho MG. A new index to discriminate between iron deficiency anemia and thalassemia trait. Rev Bras Hematol Hemoter. 2016;38:214-219. doi:10.1016/j.bjhh.2016.05.011

30. Reis FMP, Andrade RR, Rodrigues CF, Barbosa FT. Discriminant indexes to simplify the differential diagnosis between iron deficiency anemia and thalassemia minor in individuals with microcytic anemia. Rev Assoc Med Bras. 2020;66:1277-1282. doi:10.1590/18069282.66.9.1277

31. Gür E, Yıldız I, Celkan T, et al. Prevalence of anemia and the risk factors among school children in Istanbul. J Trop Pediatr. 2005;51 (6):346-350. doi:10.1093/tropej/fmi032

32. Kothari MT, Coile A, Huestis A, Pullum T, Garrett D, Engmann C. Exploring associations between water, sanitation, and anemia through 47 nationally representative demographic and health surveys. Ann N Y Acad Sci. 2019;1450(1):249-267. doi:10.1111/nyas.14109
Journal of Blood Medicine

\section{Publish your work in this journal}

The Journal of Blood Medicine is an international, peer-reviewed, open access, online journal publishing laboratory, experimental and clinical aspects of all aspect pertaining to blood based medicine including but not limited to: Transfusion Medicine; Blood collection, Donor issues, Transmittable diseases, and Blood banking logistics; Immunohematology; Artificial and alternative blood based therapeutics; Hematology; Biotechnology/nanotechnology of blood related medicine; Legal aspects of blood medicine; Historical perspectives. The manuscript management system is completely online and includes a very quick and fair peer-review system. Visit http://www.dovepress.com/testimonials.php to read real quotes from published authors. 